\title{
Sodium-Potassium-Activated Adenosine Triphosphatase of Brain Microsomes: Modification of Sodium Inhibition by Diphenylhydantoins
}

\author{
George J. Siegel and Beverly B. Goodwin \\ From the Departments of Neurology and Physiology, Mount Sinai School of \\ Medicine of the City University of New York, New York 10029 and the \\ Institute for Medical Research and Studies, New York 10010
}

A в S T R A C T Effects of diphenylhydantoins on $\left(\mathrm{Na}^{+}\right.$ $+\mathrm{K}^{+}$)-ATPase activity in rat and cat brain microsomes were studied. 5,5-diphenylhydantoin (DPH) in concentrations of $5-20 \mu \mathrm{g} \cdot \mathrm{ml}^{-1}$ produces an apparent stimulation of the rat brain $\left(\mathrm{Na}^{+}+\mathrm{K}^{+}\right)$-activated ATPase of $55-65 \%$ in media containing $50 \mathrm{~mm} \mathrm{Na} \mathrm{Na}^{+}, 0.15 \mathrm{~mm} \mathrm{~K}$, $3 \mathrm{mM} \mathrm{Mg}^{++}$, and $3 \mathrm{~mm}$ ATP. No effects are found on the Mg-ATPase. At constant $\mathrm{K}^{+}$levels of $0.05 \mathrm{mmole} / \mathrm{liter}$ and $0.15 \mathrm{mmole} /$ liter, increasing the $\mathrm{Na}^{+}$concentration activates the enzyme similarly with and without DPH. However, $\mathrm{Na}^{+}$concentrations greater than 5 mmoles/ liter and $10 \mathrm{mmoles} / \mathrm{liter}$, respectively, which are inhibitory in these low $\mathrm{K}^{+}$media, produce less inhibition in the presence of DPH. In media containing $10 \mathrm{mM}$ $\mathrm{Na}^{+}$, the $\mathrm{K}^{+}$activation, on the other hand, is potentiated by DPH. In preparations from cat brain qualitatively similar results are obtained. No effect of DPH is seen on the inhibition produced by high $\mathrm{K}^{+}$in low $\mathrm{Na}^{+}$media. DPH produces an approximately constant apparent stimulation of $45 \%$ in the $\left(\mathrm{Na}^{+}+\mathrm{K}^{+}\right)$increments when these ions are varied simultaneously at a fixed ratio of $150 \mathrm{Na}^{+}: 1 \mathrm{~K}^{+}$with cat brain extracts. 5-( $p$-hydroxyphenyl)-5-phenylhydantoin (HPPH) has the same potency as DPH in reducing the $\mathrm{Na}^{+}$inhibition at high $\mathrm{Na}: \mathrm{K}$ ratios. The hydantoins appear to act by decreasing the $\mathrm{Na}^{+}$inhibition that occurs at high $\mathrm{Na}: \mathrm{K}$ ratios.

Presented in part at the 23rd Annual Meeting, American Academy of Neurology, 30 April 1971, New York.

Received for publication 21 September 1971 and in revised form 11 November 1971.

\section{INTRODUCTION}

Diphenylhydantoin (DPH $)^{1}$ has been observed to reduce the intracellular sodium ion concentration and to increase $\mathrm{Na}^{+}$concentrations in brains of rats subjected to electroshock seizures. It was therefore proposed that the anti-seizure action of DPH results from stimulation of a metabolically linked process of active $\mathrm{Na}^{+}$extrusion (1). There is now considerable evidence that active $\mathrm{Na}^{+}$transport is linked to $\left(\mathrm{Na}^{+}+\mathrm{K}^{+}\right)$-activated adenosine triphosphatase $(2,3)$. Studies on this enzyme have shown that DPH inhibits the enzyme activity in brain microsome extracts (4) and in synaptosomal preparations $(5,6)$ under conditions of low $\mathrm{Na}: \mathrm{K}$ ratios although it appears to stimulate enzyme activity in synaptosomes under high $\mathrm{Na}: \mathrm{K}$ ratios (5). In addition, DPH stimulates $\mathrm{K}^{+}$transport under certain conditions in synaptosomes (7). The present study is a further attempt to characterize the effects of hydantoins on brain microsomal $\left(\mathrm{Na}^{+}+\mathrm{K}^{+}\right)$-ATPase. It is found that DPH and its hydroxylated derivative, 5-( $p$-hydroxyphenyl)-5-phenylhydantoin (HPPH), both act to decrease the inhibition of $\left(\mathrm{Na}^{+}+\mathrm{K}^{+}\right)$-ATPase produced by high $\mathrm{Na}: \mathrm{K}$ ratios.

\section{METHODS}

Materials. Tris-ATP and the sodium salt of 5,5-diphenylhydantoin (DPH) were obtained from Sigma Chemical Co., St. Louis, Mo.; [ $\left.\gamma^{-2} \mathrm{P}\right]-A T P$ was obtained from International Chemical and Nuclear Corp., Irvine, Calif.; and 5-( $p$-hydroxyphenyl)-5-phenylhydantoin ( $\mathrm{HPPH})$ was a generous gift from Dr. Henn Kutt (8). Diazepam was

${ }^{1}$ Abbreviations used in this paper: ATPase, adenosine triphosphatase; DPH, diphenylhantoin; EDTA, ethylenediaminetetraacetate; HPPH, 5-( $p$-hydroxyphenyl)-5-phenylhydantoin. 
generously supplied by Roche Laboratories, Nutley, N. J. Sodium Phenobarbital Injection, $(130 \mathrm{mg} / \mathrm{ml}$ in $67.8 \%$ propyleneglycol, $10 \%$ ethanol, and $1.5 \%$ benzyl alcohol) was obtained from USV Pharmaceutical Corp., New York. This was diluted 4000 -fold in the enzyme assay media. DPH and $\mathrm{HPPH}$ suspensions in water were made at the time of use. In some experiments where noted, sodium DPH was dissolved in Parke, Davis Solvent for Dilantin (40\% propylene glycol, $10 \%$ ethanol, adjusted with $\mathrm{NaOH}$ to $\mathrm{pH}$ 12; Parke, Davis \& Co., Detroit, Mich.) this solvent was diluted 1750 -fold in the enzyme assay media. Diazepam was dissolved in the Parke, Davis Solvent and similarly diluted in the enzyme assay.

Microsomal $\left(\mathrm{Na}^{+}+\mathrm{K}^{+}\right)$-ATPase was prepared from rat and cat brains in a procedure using $\mathrm{NaI}(9)$ and stored in liquid nitrogen. Protein was measured by the method of Lowry, Rosebrough, Farr, and Randall (10).

Assay of $\left(\mathrm{Na}^{+}+\mathrm{K}^{+}\right)-A T P a s e$. Brain microsomes were diluted at the time of assay in $0.05 \mathrm{M}$ Tris- $\mathrm{HCl}(\mathrm{pH} 7.4)$ containing $0.1 \mathrm{~mm}$ Tris-EDTA. Microsomes, 5-30 $\mu \mathrm{g}$ protein, were incubated at $37^{\circ} \mathrm{C}$ for $30 \mathrm{~min}$ in $0.05 \mathrm{M}$ Tris$\mathrm{HCl}$ ( $\mathrm{pH}$ 7.4), $3 \mathrm{~mm} \mathrm{MgCl}_{2}, 3 \mathrm{~mm}$ Tris- $\left[\gamma^{-2} \mathrm{P}\right]-\mathrm{ATP}$ (specific activity $10^{5} \mathrm{cpm} / \mu$ mole) plus $\mathrm{NaCl}$ and $\mathrm{KCl}$ as indicated, in final volumes of $40 \mu 1$. The enzyme was preincubated for $15 \mathrm{~min}$ at $0^{\circ} \mathrm{C}$ in the test agent plus the indicated salts before initiation of reaction with ATP. Reactions were terminated by the addition of $10 \mu \mathrm{l}$ of $50 \%$ cold trichloroacetic acid. Inorganic phosphate was extracted in isobutanol and the radioactivity measured as described (11). $\left(\mathrm{Na}^{+}+\mathrm{K}^{+}\right)$-ATPase activity was obtained by subtracting the hydrolytic rate in the presence of $\mathrm{Mg}^{++}$from the total rate in $\mathrm{Mg}^{++}, \mathrm{Na}^{+}$, and $\mathrm{K}^{+}$. It was ascertained that pretreatment of microsomes with $0.1 \mathrm{~mm}$ ouabain in $3 \mathrm{mM} \mathrm{MgCl}_{2}$ for $30 \mathrm{~min}$ at $\mathrm{O}^{\circ} \mathrm{C}$ abolished $95 \%$ of the $\left(\mathrm{Na}^{+}\right.$ $+\mathrm{K}^{+}$) increments.

\section{RESULTS}

During preliminary experiments, it was found that DPH stimulates $\left(\mathrm{Na}^{+}+\mathrm{K}^{+}\right)$-ATPase activity of rat or cat brain microsomes in the presence of $150 \mathrm{~mm}$ $\mathrm{Na}^{+}$and $1 \mathrm{~mm} \mathrm{~K} \mathrm{~K}^{+}$. Apparent stimulation of the $\left(\mathrm{Na}^{+}\right.$

TABLE I

Stimulation of Rat Brain $\left(\mathrm{Na}^{+}+K^{+}\right)-$ATPase by Hydantoins

\begin{tabular}{cccccc}
\hline $\mathrm{DPH}$ & $\Delta \mathrm{Mg}^{2+}$ & $\Delta\left(\mathrm{Na}^{+}+\mathrm{K}^{+}\right) *$ & $\mathrm{HPPH}$ & $\Delta\left(\mathrm{Na}^{+}+\mathrm{K}^{+}\right) \ddagger$ & $\Delta \mathrm{Mg}^{2+}$ \\
\hline$\mu g \cdot m l^{-1}$ & \multicolumn{2}{c}{$\%$ control } & $\mu \mathrm{c} \cdot \mathrm{ml}^{-1}$ & \multicolumn{2}{c}{$\%$ control } \\
2.5 & 101 & 105 & 1.5 & 98 & \\
5.0 & 104 & 153 & 3.1 & 141 & \\
10.0 & 108 & 155 & 12.5 & 171 & \\
20.0 & 95 & 167 & 25.0 & 171 & 105 \\
\hline
\end{tabular}

Other conditions as described in Methods. Control values (nmoles $\cdot \mathrm{mg}^{-1} \cdot \mathrm{min}^{-1}$ ): DPH experiment, $\Delta \mathrm{Mg}^{2+}=58$, $\Delta\left(\mathrm{Na}^{+}+\mathrm{K}^{+}\right)=43 ; \mathrm{HPPH}$ experiment, $\Delta \mathrm{Mg}^{+}=122$, $\Delta\left(\mathrm{Na}^{+}+\mathrm{K}^{+}\right)=119$.

* $50 \mathrm{~mm} \mathrm{NaCl}$ plus $0.15 \mathrm{~mm} \mathrm{KCl}$.

$\ddagger 150 \mathrm{~mm} \mathrm{NaCl}$ plus $1 \mathrm{~mm} \mathrm{KCl}$.

${ }^{2}$ Under the same cation conditions, DPH, $20 \mu \mathrm{g} \cdot \mathrm{ml}^{-1}$, had no significant effect on $\left(\mathrm{Na}^{+}+\mathrm{K}^{+}\right)$-ATPase in electroplax microsomes from Electrophorus electricus.
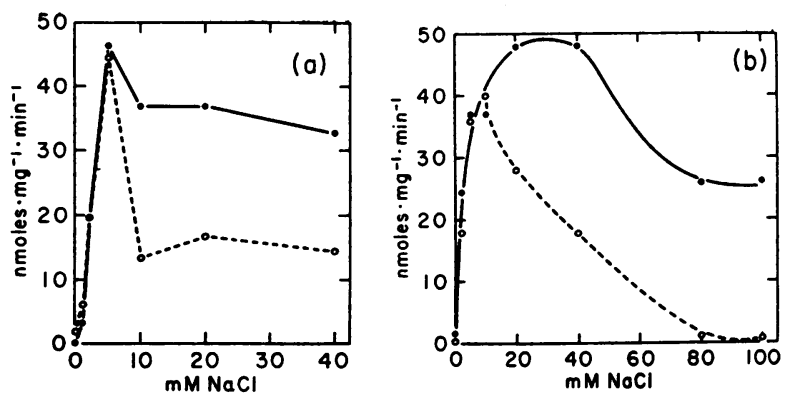

FiguRE 1 Effects of DPH on rat brain $\left(\mathrm{Na}^{+}+\mathrm{K}^{+}\right)$-ATPase under varying $\mathrm{Na}^{+}$concentration (a) $0.05 \mathrm{~mm} \mathrm{KCl}$. (b) $0.15 \mathrm{~mm} \mathrm{KCl}$. Other conditions as described in Methods. O--O, control; $\bullet-\bullet$, DPH $20 \mu \mathrm{g} \cdot \mathrm{ml}^{-1}$.

$+\mathrm{K}^{+}$) increments in ATPase activity is produced by $\mathrm{DPH}$ or $\mathrm{HPPH}$ in concentrations as low as $3-5 \mu \mathrm{g} \cdot \mathrm{ml}^{-1}$ (Table I). The largest effects are seen with concentrations of $20-25 \mu \mathrm{g} \cdot \mathrm{ml}^{-1}$. No significant effects on the $\mathrm{Mg}^{2+}$-ATPase activity are seen.

The activation of ATPase activity by sodium ion is shown in Fig. $1 a$ and $b$. In separate experiments performed in constant $\mathrm{K}^{+}$concentrations of $0.05 \mathrm{mmole} /$ liter and $0.15 \mathrm{mmole} / \mathrm{liter}$, sodium ion is inhibitory in the range of 10 and 20 mmoles/liter, respectively. However, in both cases, the sodium inhibition is reduced in the presence of DPH $20 \mu \mathrm{g} \cdot \mathrm{ml}^{-1}$. On the other hand, the sodium activation is not significantly altered by the $\mathrm{DPH}$.

Fig. 2 shows the effect of DPH on potassium ion activation in $10 \mathrm{~mm} \mathrm{NaCl}$. DPH appears to potentiate activation by the low $\mathrm{K}^{+}$concentrations where the $\mathrm{Na}: \mathrm{K}$ ratio is high relative to the ratio which produces optimal activation. This effect is negligible when

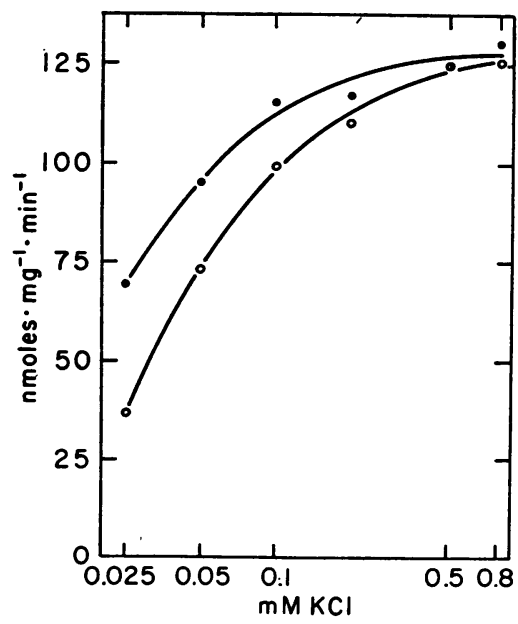

FIGURE 2 Effect of $\mathrm{DPH}$ on rat brain $\left(\mathrm{Na}^{+}+\mathrm{K}^{+}\right)$-ATPase under varying $\mathrm{K}^{+}$concentration in $10 \mathrm{~mm} \mathrm{NaCl}$. Other conditions as described in Methods. $\mathrm{O}-\mathrm{O}$, control; DPH $20 \mu \mathrm{g} \cdot \mathrm{ml}^{-1}$. 


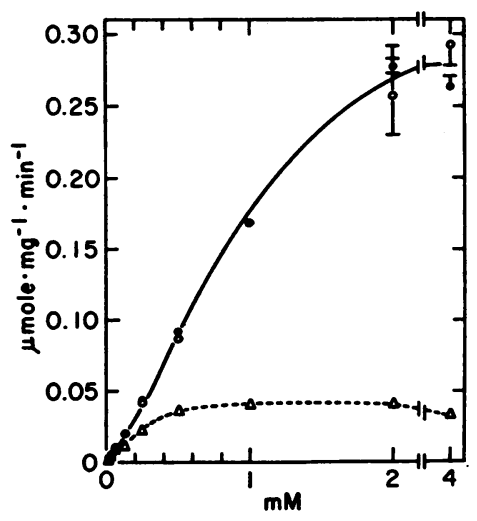

Figure 3 Activation of rat brain ATPase by ATP plus $\mathrm{MgCl}_{2}$. Tris-ATP and $\mathrm{MgCl}_{\mathbf{2}}$ were varied in equimolar proportions. Other conditions as described in Methods. $\Delta-\triangle \Delta$, no univalent cations added; solid line, $80 \mathrm{~mm}$ $\mathrm{NaCl}$ plus $5 \mathrm{~mm} \mathrm{KCl}$ added; $\mathrm{O}$, control; $\bullet, \mathrm{DPH} 22$ $\mu \mathrm{g} \cdot \mathrm{ml}^{-1}$.

maximum rates are obtained at the optimal $\mathrm{Na}: \mathrm{K}$ ratio. The absence of any significant DPH effect in the presence of $80 \mathrm{~mm} \mathrm{Na}{ }^{+}$plus $5 \mathrm{~mm} \mathrm{~K} \mathrm{~K}^{+}$is confirmed in Fig. 3. Thus, the principal effect of DPH is not on the maximum velocity but rather on the inhibition seen at high $\mathrm{Na}: \mathrm{K}$ ratios. This may be manifested as an increase in the observed velocity which is a resultant of both the stimulatory and inhibitory cationic effects. The DPH effect is most reproducible under conditions of $150 \mathrm{mM} \mathrm{Na}^{+}$and $1 \mathrm{mM} \mathrm{K} \mathrm{K}^{+}$, taking into account the amount of enzyme activity required for reliable measurements under these conditions.

$\mathrm{HPPH}$ has the same effect as DPH in reducing the sodium ion inhibition at high $\mathrm{Na}: \mathrm{K}$ ratios (Fig. 4). No effect is seen on the activation phase of the $\mathrm{Na}^{+}$ curve. Table II compares the effects of DPH and $\mathrm{HPPH}$ with phenobarbital and diazepam in the same experiment under identical conditions and shows that both HPPH and DPH produce an apparent stimulation

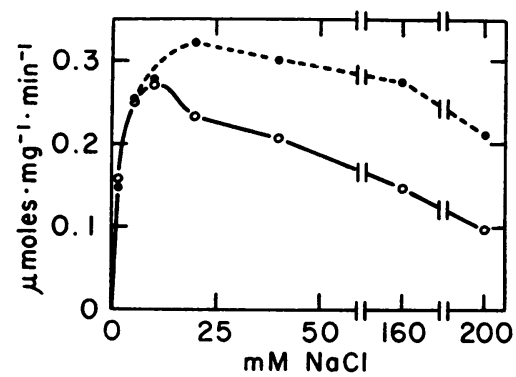

Figure 4 Effect of $\mathrm{HPPH}$ on rat brain $\left(\mathrm{Na}^{+}+\mathrm{K}^{+}\right)$-ATPase under varying $\mathrm{Na}^{+}$concentration in $0.5 \mathrm{~mm} \mathrm{KCl}$. Assay media contained 1:1750 dilution of Parke, Davis Solvent. Other conditions as described in Methods. $\mathrm{O}-\mathrm{O}$, control; - - •, HPPH $25 \mu \mathrm{g} \cdot \mathrm{ml}^{-1}$.
TABLE II

Effects of Hydantoins on Rat Brain $\left(\mathrm{Na}^{+}+\mathrm{K}^{+}\right)$-ATPase at High $\mathrm{Na}^{+}: \mathrm{K}^{+}$Ralio $^{*}$

\begin{tabular}{lcccc}
\hline \multicolumn{1}{c}{ Addition } & $\mathrm{Mg}^{++}$ & $\mathrm{Mg}^{++}+\mathrm{Na}^{+}+\mathrm{K}^{+} \Delta\left(\mathrm{Na}^{+}+\mathrm{K}^{+}\right) \%$ Control \\
\hline O.1 mmole/liter & \multicolumn{2}{c}{$\mu$ moles $\cdot \mathrm{mg}^{-1} \cdot$ min $^{-1}($ SEM $)$} \\
Control & $0.096(0.003)$ & $0.230(0.003)$ & 0.134 & \\
DPH & $0.092(0.002)$ & $0.357(0.012)$ & 0.265 & 198 \\
HPPH & $0.094(0.003)$ & $0.366(0.007)$ & 0.272 & 203 \\
Phenobarbital & $0.095(0.001)$ & $0.239(0.014)$ & 0.144 & 107 \\
Diazepam & $0.095(0.002)$ & $0.230(0.011)$ & 0.135 & 101 \\
\hline
\end{tabular}

Other conditions as described in Methods. DPH and diazepam were dissolved in Parke, Davis Solvent (see Methods). The final dilution of this solvent in the assay media was 1750-fold. The same amount was added to control tubes and those with HPPH. It was ascertained that this amount of solvent did not alter the enzyme activity or DPH effect. The sodium salt of phenobarbital was used as described in Methods.

* $150 \mathrm{~mm} \mathrm{NaCl}$ plus $1 \mathrm{mM} \mathrm{KCl}$.

$\ddagger \mathbf{N}=3$.

under these conditions of $103 \%$ and $98 \%$, respectively. Phenobarbital and diazepam have no significant effect under these conditions.

Microsome preparations from cat brain yield results qualitatively similar to those obtained with rat brain. In the presence of $150 \mathrm{mM} \mathrm{Na}^{+}$and $1 \mathrm{mM} \mathrm{K} \mathrm{K}^{+}$, DPH stimulates the $\left(\mathrm{Na}^{+}+\mathrm{K}^{+}\right)$-ATPase by $44 \%$ and does not affect the $\mathrm{Mg}^{2+}$-ATPase activity. The inhibition produced by pretreatment with ouabain is not altered by DPH under these conditions (Table III). Ouabain inhibition was also unaffected when microsomes were treated first with $\mathrm{DPH}$ in an experiment otherwise similar to that of Table III. Fig. 5 shows that in 0.5 $\mathrm{mm} \mathrm{K} \mathrm{K}^{+}, \mathrm{NaCl}$ activation is not altered by $\mathrm{DPH}$, whereas the inhibition in high $\mathrm{Na}^{+}$is reduced. Fig. 6 shows

TABLE III

Effects of DPH plus Ouabain on Cat Brain $\left(\mathrm{Na}^{+}+\mathrm{K}^{+}\right)-\mathrm{ATPase}$ Activity

\begin{tabular}{ccc}
\hline \multicolumn{1}{c}{ Additions } & $\Delta \mathrm{Mg}^{2+}$ & $\Delta\left(\mathrm{Na}^{+}+\mathrm{K}^{+}\right) *$ \\
\hline Ouabain $(0.05 \mathrm{mM})$ & 96 & \% of control \\
DPH $\left(20 \mu \mathrm{g} \cdot \mathrm{ml}^{-1}\right)$ & 97 & 144.9 \\
Ouabain plus DPH & & 5.9 \\
\hline
\end{tabular}

Microsomes were pretreated in $0.05 \mathrm{~mm}$ ouabain, $25 \mathrm{mM}$ Tris- $\mathrm{HCl}$ (pH 7.4), and $1.5 \mathrm{mM} \mathrm{MgCl}_{2}$ at $0^{\circ} \mathrm{C}$ for $30 \mathrm{~min}$. The ouabain-treated microsomes were then preincubated an additional $15 \mathrm{~min}$ at $0^{\circ} \mathrm{C}$ with and without $\mathrm{DPH}$ and finally assayed for ATPase activity for $30 \mathrm{~min}$ at $37^{\circ} \mathrm{C}$ as described in Methods. Ouabain concentrations in the pretreated samples were constant throughout the assay. Controls were preincubated for identical periods.

Control values $\left(\mathrm{nmoles} \cdot \mathrm{mg}^{-1} \cdot \mathrm{min}^{-1}\right): \Delta \mathrm{Mg}^{2+}=10.2$, $\Delta\left(\mathrm{Na}^{+}+\mathrm{K}^{+}\right)=20.3$.

* $150 \mathrm{~mm} \mathrm{NaCl}$ plus $1 \mathrm{~mm} \mathrm{KCl}$. 


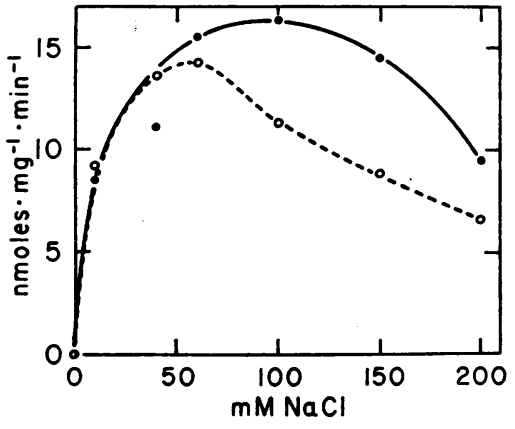

Figure 5 Effect of DPH on cat brain $\left(\mathrm{Na}^{+}+\mathrm{K}^{+}\right)$-ATPase under varying $\mathrm{Na}^{+}$concentration in $0.5 \mathrm{~mm} \mathrm{KCl}$. Other conditions as described in Methods. $\mathrm{O}-\mathrm{O}$, control; $-\bullet$, DPH $20 \mu \mathrm{g} \cdot \mathrm{ml}^{-1}$.

that in $150 \mathrm{~mm} \mathrm{NaCl}$, the $\mathrm{K}^{+}$activation is further increased by $\mathrm{DPH}$ where the $\mathrm{Na}: \mathrm{K}$ ratio is large, as in the case of rat brain. No significant DPH effect was found at optimal cation ratios. In a separate experiment performed with $150 \mathrm{~mm} \mathrm{NaCl}$ as in Fig. 6, but with higher $\mathrm{KCl}$ concentrations, the maximal observed rates were obtained with $12.5 \mathrm{~mm} \mathrm{KCl}: 31.2$ and 34.9 nmoles $\cdot \mathrm{mg}^{-1} \cdot \mathrm{min}^{-1}$ for control and DPH treated samples, respectively. These rates did not vary significantly at $\mathrm{KCl}$ levels from 12.5 to 100 mmoles/liter. Their averages over this range were, in $\mathrm{nmoles} \cdot \mathrm{mg}^{-1} \cdot \mathrm{min}^{-1}: 30.3$ (SEM 0.37) for control and 31.5 (SEM 1.25) for DPH samples $(n=4)$.

The effects of high $\mathrm{KCl}$ concentrations in low $[\mathrm{NaCl}]$ are shown in Fig. 7. In 10 mmoles/liter of $\mathrm{NaCl}$ inhibition by $\mathrm{K}^{+}$occurs in concentrations of $10 \mathrm{mmoles} /$ liter or higher and this action of $\mathrm{K}^{+}$is not appreciably altered by $\mathrm{DPH}$. Hence, the inhibition due to high $\mathrm{K}: \mathrm{Na}$ ratios is not affected by $\mathrm{DPH}$, in contrast to inhibition

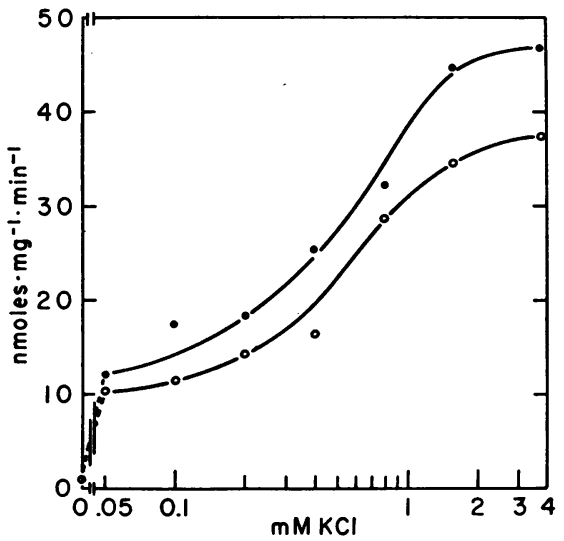

FIgURE 6 Effect of DPH on cat brain $\left(\mathrm{Na}^{+}+\mathrm{K}^{+}\right)$-ATPase under varying $\mathrm{K}^{+}$concentration in $150 \mathrm{~mm} \mathrm{NaCl}$. Other conditions as described in Methods. $\mathrm{O}-\mathrm{O}$, control; $-\bullet$, $\mathrm{DPH} 20 \mu \mathrm{g} \cdot \mathrm{ml}^{-1}$.

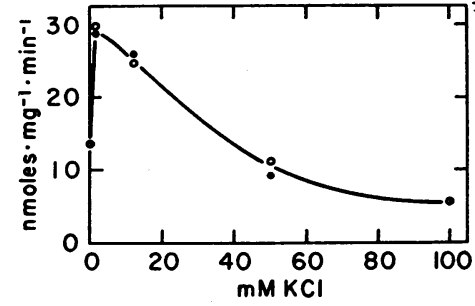

FIgURE 7 Inhibition of cat brain $\left(\mathrm{Na}^{+}+\mathrm{K}^{+}\right)$-ATPase by excess $\mathrm{K}^{+}$in $10 \mathrm{~mm} \mathrm{NaCl}$. Other conditions as described in Methods. $O$, control; $\bullet, \mathrm{DPH} 20 \mu \mathrm{g} \cdot \mathrm{ml}^{-1}$.

by high $\mathrm{Na}: \mathrm{K}$ ratios. This observation is shown also when $\mathrm{Na}^{+}$is varied; i.e., no effect of $\mathrm{DPH}$ is seen on the activation by low $\mathrm{Na}^{+}$concentrations where the $\mathrm{K}: \mathrm{Na}$ ratio is high (Figs. 1, 4, and 5). When the sodium and potassium ion concentrations are varied simultaneously to maintain a constant ratio of $\mathrm{Na}: \mathrm{K}$ $=150, \mathrm{DPH}$ produces an average apparent stimulation of about $45 \%$ in the $\left(\mathrm{Na}^{+}+\mathrm{K}^{+}\right)$increments throughout the total cation concentration range (Fig. 8). Thus, the DPH effect is independent of total ionic strength and of the concentration of either cation alone.

\section{DISCUSSION}

There is evidence that the $\left(\mathrm{Na}^{+}+\mathrm{K}^{+}\right)$-activated ATP hydrolysis proceeds through a multi-stage reaction mechanism in which $\mathrm{Na}^{+}$activates enzyme phosphorylation and $\mathrm{K}^{+}$activates enzyme dephosphorylation (3, 11). It is well known that excesses of either $\mathrm{Na}^{+}$or $\mathrm{K}^{+}$exert inhibition of a mutually competitive nature $(12,13)$, but there is disagreement on the basis of

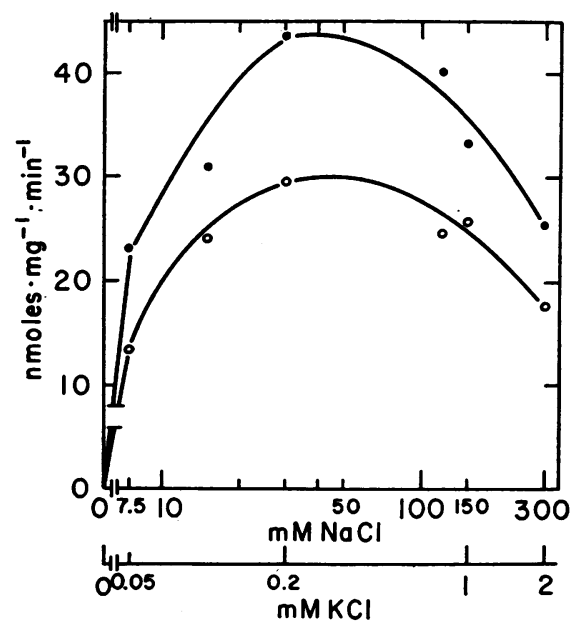

FIgURE 8 Effect of DPH on cat brain $\left(\mathrm{Na}^{+}+\mathrm{K}^{+}\right)$-ATPase. $\mathrm{NaCl}$ and $\mathrm{KCl}$ were varied simultaneously in the proportion of $150: 1$. Other conditions as described in Methods. $\mathrm{O}-\mathrm{O}$, control; $-\bullet, \mathrm{DPH} 20 \mu \mathrm{g} \cdot \mathrm{ml}^{-1}$. 
kinetic data as to whether the respective binding sites are necessarily separate or identical. In the present study it is observed that DPH decreases the inhibition due to high $\mathrm{Na}: \mathrm{K}$ ratios but has no effect on inhibition due to relative excess of $\mathrm{K}^{+}$.

The reduction of $\mathrm{Na}^{+}$inhibition may be explained by assuming that $\mathrm{DPH}$ antagonizes the $\mathrm{Na}^{+}$effect relative to $\mathrm{K}^{+}$at a site which when occupied by $\mathrm{Na}^{+}$is inhibitory. This site might be either identical with or interacting with a $\mathrm{K}^{+}$site, for example, the site involved in dephosphorylation. Conversely, if $\mathrm{DPH}$ were also to antagonize $\mathrm{Na}^{+}$activation of enzyme phosphorylation, then one would expect to observe an apparent inhibition by $\mathrm{DPH}$ at low $\mathrm{Na}: \mathrm{K}$ ratios. This was not observed in the present study. In addition, it has been reported that $\mathrm{DPH}$ has no effect on myocardial $\left(\mathrm{Na}^{+}+\mathrm{K}^{+}\right)$ATPase activity in the presence of $100 \mathrm{~mm} \mathrm{Na}{ }^{+}$plus $10 \mathrm{~mm} \mathrm{~K} \mathrm{~K}^{+}(14)$. The fact that such inhibition by $\mathrm{DPH}$ was, however, reported at low $\mathrm{Na}: \mathrm{K}$ ratios in other types of brain enzyme preparations (4-6) might indicate that under certain conditions more of the cation binding sites become susceptible to the $\mathrm{DPH}$ action. Further information on the mechanism of the $\mathrm{DPH}$ effect may be obtained from direct studies of the phosphorylation and ATP-ADP transphosphorylation reactions (11).

An important question is whether the observed $\mathrm{DPH}$ effect on $\left(\mathrm{Na}^{+}+\mathrm{K}^{+}\right)$-ATPase can be related to the drug's anti-seizure activity. Woodbury observed a direct correlation between the ratio of extracellular to intracellular brain sodium ion concentration and the electroshock seizure threshold in rats. Based on the observations that DPH increased the rate of sodium flux in normal rat brains and decreased the intracellular brain sodium concentrations in normal rats and in rats subjected to electroshock seizures, he proposed that the anti-seizure activity results from stimulation of active sodium extrusion (1). Festoff and Appel (5) found that DPH appears to stimulate $\left(\mathrm{Na}^{+}+\mathrm{K}^{+}\right)$-ATPase activity in synaptosomes from rat cerebrum when the $\mathrm{Na}: \mathrm{K}$ ratio is in the range $50: 1$. The experiments reported here with $\mathrm{NaI}$-extracted brain microsomes confirm the apparent stimulatory effect of $\mathrm{DPH}$ at high $\mathrm{Na}: \mathrm{K}$ ratios and show that this effect results from a decrease in $\mathrm{Na}^{+}$inhibition. No qualitative difference between rat and cat brain preparations regarding this effect was noted under the conditions tested. Although the optimal condition for the effect in this study is a $\mathrm{Na}: \mathrm{K}$ ratio of $150: 1$, this value is quite broad and differences in this ratio may be due to differences in membrane preparations used, extraction procedures, or relative extents of $\mathrm{Na}^{+}$inhibition. Of greater significance is the fact that the DPH effect depends on specific ionic proportions in the range which can regulate the enzyme activity.

Regulation of $\left(\mathrm{Na}^{+}+\mathrm{K}^{+}\right)$-ATPase is complicated; it depends on a balance among both activation and inhibition effects by both sodium and potassium. It has been found in studies of red cells that activation of the sodium pump and $\left(\mathrm{Na}^{+}+\mathrm{K}^{+}\right)$-ATPase is due to intracellular $\mathrm{Na}^{+}$and extracellular $\mathrm{K}^{+}$while, on the other hand, extracellular $\mathrm{Na}^{+}$is inhibitory $(15,16)$. It is plausible that in vivo $\mathrm{DPH}$ might produce an increased rate of transport under a given set of conditions through a reduction in the relative inhibition due to extracellular $\mathrm{Na}^{+}$similar to its effect on $\left(\mathrm{Na}^{+}+\mathrm{K}^{+}\right)$ATPase in vitro. However, as described above, other studies have indicated an inhibitory effect of DPH at low $\mathrm{Na}: \mathrm{K}$ ratios which suggests that $\mathrm{DPH}$ under some conditions may also decrease $\mathrm{Na}^{+}$activation. Therefore, the net result of the $\mathrm{DPH}$ action will depend on its relative effects on the two $\mathrm{Na}^{+}$actions.

It is difficult to draw comparisons on a molecular basis between actions on $\left(\mathrm{Na}^{+}+\mathrm{K}^{+}\right)$-ATPase in vitro and anti-seizure activity because other factors such as absorption, metabolism, excretion, and permeability might limit a drug's potency in vivo. $\mathrm{HPPH}$ in very high doses was reported ineffective against electroshock-induced seizures in rats (17) yet it exhibits the same potency as $\mathrm{DPH}$ in its effects on $\left(\mathrm{Na}^{+}+\mathrm{K}^{+}\right)$ATPase. HPPH is the main excretory product of $\mathrm{DPH}$ (18) and is found conjugated with glucuronic acid in the urine (19). The liver is an important site for the formation of $\mathrm{HPPH}$ (8). If the action on $\left(\mathrm{Na}^{+}+\mathrm{K}^{+}\right)$ATPase is critical for the anti-seizure activity of the hydantoins, then it might be supposed that the nervous system action of $\mathrm{HPPH}$ is limited by a more rapid rate of excretion or decreased permeation into brain in the conjugated form rather than by hydroxylation per se. Alternatively, it remains possible that the hydantoin action as measured on $\left(\mathrm{Na}^{+}+\mathrm{K}^{+}\right)$-ATPase in vitro is itself not sufficient to account for the antiseizure activity of the hydantoins. Studies of HPPH metabolism and concentration within the brain may help answer these questions.

The observation that $\mathrm{DPH}$ stimulates the $\left(\mathrm{Na}^{+}+\right.$ $\mathrm{K}^{+}$)-ATPase, although consistent with Woodbury's hypothesis, is not confirmatory, as discussed by several authors $(5,20)$. In addition, recent studies with lobster nerves have shown that $\mathrm{DPH}$ is able to lower the intraneuronal $\mathrm{Na}^{+}$concentration without affecting $\mathrm{K}^{+}$in the presence of ouabain or cyanide inhibition (21). Thus, DPH has multiple actions that may modify $\mathrm{Na}^{+}$translocation and it is not known which of these, if not a combination, is important physiologically in the control of seizures. Further physiologic studies comparing $\mathrm{HPPH}$ and $\mathrm{DPH}$ effects on seizures and on 
membrane properties in vitro will be pertinent to this issue.

\section{ACKNOWLEDGMENTS}

This work was supported partially by Grant MH 13692 from the National Institute of Mental Health and Grant GB 8754 from The National Science Foundation.

\section{REFERENCES}

1. Woodbury, D. M. 1955. Effect of diphenylhydantoin on electrolytes and radiosodium turnover in brain and other tissues of normal, hyponatremic and postictal rats. $J$. Pharmacol. Exp. Therap. 115: 74.

2. Skou, J. C. 1960. Further investigations on a $\mathrm{Mg}^{2+}+$ $\mathrm{Na}^{+}$-activated adenosinetriphosphatase, possibly related to the active, linked transport of $\mathrm{Na}^{+}$and $\mathrm{K}^{+}$across the nerve membrane. Biochim. Biophys. Acta. 42: 6.

3. Albers, R. W. 1967. Biochemical aspects of active transport. Ann. Rev. Biochem. 36: 727.

4. Rawson, M. D., and J. H. Pincus. 1968. The effect of diphenylhydantoin on sodium, potassium, magnesiumactivated adenosine triphosphatase in microsomal fractions of rat and guinea pig brain and on whole homogenates of human brain. Biochem. Pharmacol. 17: 573.

5. Festoff, B. W., and S. H. Appel. 1968. Effect of diphenylhydantoin on synaptosome sodium-potassiumATPase. J. Clin. Invest. $47: 2752$.

6. Formby, B. 1970. The in vivo and in vitro effect of diphenylhydantoin and phenobarbitone on $\mathrm{K}^{+}$-activated phospholydrolase and $\left(\mathrm{Na}^{+}, \mathrm{K}^{+}\right)$-activated ATPase in particulate membrane fractions from rat brain. J.Pharm. Pharmacol. 22: 81 .

7. Escueta, A. V., and E. L. Reilly. 1971. The effects of diphenylhydantoin on potassium transport within synaptic terminals of the epileptogenic foci. Neurology. 21: 418.

8. Kutt, H., and K. Verebely. 1970. Metabolism of diphenylhydantoin by rat liver microsomes. I. Characteristics of the reaction. Biochem. Pharmacol. 19: 675.

9. Albers, R. W., G. J. Koval, and G. J. Siegel. 1968. Studies on the interaction of ouabain and other cardio- active steroids with sodium-potassium-activated adenosine triphosphatase. Mol. Pharmacol. 4: 324.

10. Lawry, O. H., N. J. Rosebrough, A. L. Farr, and R. J. Randall. 1951. Protein measurement with the Folin phenol reagent. J. Biol. Chem. 193: 265.

11. Siegel, G. J., and R. W. Albers. 1967. Sodium-potassium-activated adenosine triphosphatase of Electrophorus electric organ. IV. Modification of responses to sodium and potassium by arsenite plus 2,3-dimercaptopropanol. J. Biol. Chem. 242 : 4972.

12. Ahmed, K., J. D. Judah, and P. G. Scholefield. 1966. Interaction of $\mathrm{Na}^{+}$and $\mathrm{K}^{+}$with a cation-dependent ATPase system from rat brain. Biochim. Biophys. Acta. 120: 351 .

13. Robinson, J. D. 1970. Interactions between monovalent cations and the $\left(\mathrm{Na}^{+}+\mathrm{K}^{+}\right)$-dependent adenosine triphosphatase. Arch. Biochem. Biophys. 139: 17.

14. Gibson, K., and P. Harris. 1969. Dephenylhydantoin and human myocardial microsomal $\left(\mathrm{Na}^{+}, \mathrm{K}^{+}\right)$-ATPase. Biochem. Biophys. Res. Commun. 35: 75.

15. Garrahan, P. J., and I. M. Glynn. 1967. The sensitivity of the sodium pump to external sodium. J. Physiol. 192: 175.

16. Priestland, R. N., and R. Whittam. 1968. The influence of external sodium ions on the sodium pump in erythrocytes. Biochem. J. 109: 369.

17. Nitz, R. E., W. Persch, and A. Schmidt. 1955. Zur chemie und antikonvulsiven Wirkung neuer Hydantoinderivate. Arzneimittel-Forschung. 5: 357.

18. Butler, T. C. 1957. The metabolic conversion of 5,5diphenylhydantoin to 5-( $p$-hydroxyphenyl)-5-phenylhydantoin. J. Pharmacol. Exp. Therap. 119: 1.

19. Maynert, E. W. 1960. The metabolic fate of diphenylhydantoin in the dog, rat, and man. J. Pharmacol. Exp. Therap. $130: 275$.

20. Crane, P., and P. D. Swanson. 1970. Diphenylhydantoin and the cations and phosphates of electrically stimulated brain slices. Neurology. 20: 1119.

21. Pincus, J. H., I. Grove, B. B. Marino, and G. E. Glaser. 1970. Studies on the mechanism of action of diphenylhydantoin. Arch. Neurol. 22: 566. 